UDC 341.231

DOI https://doi.org/10.32837/yuv.v0i5.2257

Kh. Rionidze,

PhD Student at the Department of the European Union Law Yaroslav Mudryi National Law University

\title{
THE EVOLUTION OF GENDER EQUALITY INTERNATIONAL LEGAL REGULATION
}

Formulation of the problem. Today, there is a fairly extensive system of universal and regional international organizations, as well as organizations at the national level that deal with the promotion and protection of human rights, including women's rights. International standards in the field of human rights protection, including gender equality, are enshrined in various international legal acts: conventions, declarations, resolutions, regulations, directives, etc.

The principle of non-discrimination on the basis of sex is affirmed in the Universal Declaration of Human Rights (UDHR), the International Covenant on Economic, Social and Cultural Rights (ICESCR), the International Covenant on Civil and Political Right (ICCPR), Convention on the Political Rights of Women, the Convention on the Elimination of All Forms of Discrimination against Women (CEDAW), as well as in regional human rights treaties such as the European Convention for the Protection of Human Rights and Fundamental Freedoms (ECHR), the American Convention on Human Rights (ACHR) and the African Charter on Human and Peoples' Rights (ACHPR).

International institutions consider gender equality as one of the priorities of human development, which is reflected in their strategies. International organizations focus on gender equality not only with from the point of view of social justice, and consider equality as resource of socio-economic development. Thus, institutionalization gender equality is gaining momentum. Despite a wide range of international human rights instruments, in particular for women, the problem of gender discrimination still exists.

Analysis of the latest researches and publications. The principle of gender equality in Ukraine has been studied by such scientists as V. Akulenko, V. Butkevych, O. Voronina, L. Voronko, L. Gonyukova, L. Guslyakova, G. Daudova, O. Dashkovska, I. Zherebkina, T. Isayeva, N. Kaminska, V. Korzhenko, I. Lazar, O. Levchenko, T. Melnyk, N. Hrytsyak, T. Omelchenko, V. Sychova, O. Kharitonova, O. Uvarova and others. Among foreign researchers are S. Aivazov, V. Bryson, E. Ghani, D. Gomien, R. Debnath, S. Jacquaot, J. Kantola, J. Mertus, I. Rubin, M.S. Rumyantsev, D. Thomas and others.

Formulation of the aim and objectives of the article. The aim of the scientific article is to make a general analysis of the development of the principle of gender equality and its legal regulation in international law. Recently, the principle of gender equality has become extremely important for Ukraine, as one of the conditions for European integration.

Basic research material. The United Nations (UN) attributes this problem to the category of global and recommends that states change the existing gender models aimed at preserving the system unequal values and double standards. Equality 
between men and women is both a value and a privilege of any society. And although in different parts of the world it is a question solved at different speeds, however the direction remains the only one.

The UDHR was adopted by the UN General Assembly at its 183rd session on 10 December 1948 as Resolution 217, which states that “... Everyone is entitled to all the rights and freedoms set forth in this Declaration, without distinction of any kind, such as race, color, sex, language, religion, political or other opinion, national or social origin, property, birth or other status..." [1].

According to

Article 2 of the 1948 UDHR, it is established that everyone should have all the rights and all freedoms proclaimed by this Declaration, without distinction of race, color, sex, language, religion, political or other beliefs, national or social origin, property, estate or other position [1]. The Declaration provided an impetus further strengthening international commitments related to women's rights. These rights were fully enshrined in the 1979 UN Convention on the Elimination of All Forms of Discrimination against Women (CEDAW) [2].

The CEDAW is a comprehensive international human rights instrument on gender equality that recognizes the equal rights of women and men, and is therefore often referred to as the International Bill of Rights for Women. It contains 30 articles which clearly define the concept of discrimination against women and propose an agenda for action at the national level to end such discrimination.

The defining stage of the struggle for gender equality was the convening of the UN initiative of four world conferences to develop a strategy and action plans to improve the situation of women. These took place in Mexico City in 1975, Copenhagen in 1980, Nairobi in 1985 and Beijing in 1995. Significant progress in the field of gen- der equality was made at the Fourth World Conference on Women in Beijing in 1995. The Beijing Declaration and Platform for Action sets out strategic goals and actions to improve the situation of women and achieve gender equality in 12 key areas: 1) Women and poverty; 2) Education and training of women; 3) Women and health; 4) Violence against women; 5) Women and armed conflicts; 6) Women and the economy; 7) Women in power and in decision-making; 8) Institutional mechanism for improving the situation of women; 9) Women's human rights; 10) Women and the media; 11) Women and the environment; 12) Girl-child [3]. The importance of these conferences should not be underestimated, because that is how it is thus a new stage in the struggle for gender equality began.

The main change was awareness of the need for reassessment the whole structure of society and the relationship between men and women inside it. Only by such a fundamental restructuring of society and its institutions women will get full opportunity to take a place as equals male partners in all walks of life. The new accents emphasized that rights women are human rights and that is gender equality is a common problem, from the solution of which is won by all. Beijing the conference inspired the world community to take over the global commitment to empowerment and opportunities for women and attracted unprecedented international attention [4].

In July 2010, the UN General Assembly established UN Women on Gender Equality to consolidate and strengthen the efforts of various UN agencies working to support intergovernmental bodies and UN member states in developing and implementing policies to promote gender equality and empowerment opportunities for women. Thus, UN member states have taken a historic step to accelerate the Organization's goals of gender equality and women's empowerment. 
Another international organization that makes considerable efforts to promote and promote the idea of gender equality is the Council of Europe, whose role is to develop and promote gender equality through the adoption of international legal instruments containing gender equality norms. The Council of Europe's work on human rights and gender equality has resulted in comprehensive legal instruments and policy guidance aimed at promoting and empowering women, as well as the effective implementation of gender equality in the Member States and beyond.

Since the $1990 \mathrm{~s}$, the Council of Europe has contributed to development gender-sensitive approach, including through the establishment of the Group of Specialists of Mainstreaming in 1995. In 1998 The Committee of Ministers of the Council of Europe has adopted a Recommendation on Gender mainstreaming. Since then, this strategy has been an integral part of the Council's work Europe to promote the full realization of gender equality.

Gender mainstreaming has gained new impetus in the Council of Europe with its inception The Transversal Program on Gender Equality (2012), which resulted adoption of the firstever Gender Equality Strategy in the history of the Council of Europe (2014-2017). The new Gender Equality Strategy for 2018-2023 provides for focus in the following strategic areas: prevention and counteraction to gender stereotypes and sexism; preventing and combating violence against women and domestic violence; ensuring equal access of women to justice; achieving a balanced participation of women and men in the adoption of political and other public decisions; protection of the rights of migrant women and girls, refugees, asylum seeker; introduction of gender mainstreaming in all policies and events [5, p. 52].
The Council of Europe Transversal Programme on Gender Equality, launched in 2012, aims to increase the impact and visibility of gender equality standards and to support their implementation in member states. In order to achieve its goal and advance the gender equality agenda, the Program relies on the political and financial support of the member states, as well as the contributions of all decision-making, advisory and monitoring bodies of the Council of Europe. The Council of Europe Gender Equality Commission (GEC) is at the centre of these efforts $[6$, p. 6]. The task of the GEC is to manage the Transversal Programme on Gender Equality, to advise and involve various components, and to establish contacts with relevant intergovernmental bodies to provide knowledge and develop a platform for discussing good practices and issues.

The Gender Equality Strategy for 2018-2023 contains an interpretation of the concept of "gender equality". Gender equality entails equal rights for women and men, girls and boys, as well as the same visibility, empowerment, responsibility and participation, in all spheres of public and private life. It also means equal access of women and men to resources and the distribution of these resources between them [7].

Strengthening the Council of Europe's commitment to gender and determination implement effective mechanisms to achieve it demonstrate appropriate Council of Europe conventions that update gender mainstreaming: Convention on Action against Trafficking in Human Beings (2005), Convention Europe on the prevention of violence against women and domestic violence (Istanbul Convention) (2011) and Convention on the Protection of Children against Sexual Exploitation and Sexual Abuse (Lanzarote Convention).

These three Council of Europe conventions have become innovative 
and comprehensive tools to protect human dignity, and they have a direct connection with the UN Sustainable Development Goals 2015-2030. The conventions are unique in that having a global character, they can be joined by any state that is not a member of the Council of Europe and has not participated in the drafting of the Convention. They were created with the understanding that measures to address global problems related to gender-based violence, human trafficking and sexual abuse exploitation of children should not be limited to a specific geographical area $[5$, p. 53].

The framework of the Istanbul Convention is based on the Four Pillars (4-P) [8, p.1]: 1) Prevention (prevent all forms of violence against women); 2) Protection (protect from all forms of violence against women); 3) Prosecution (prosecute all those accused of committing acts of violence against women); 4) Policy integration (to integrate policies, i.e. to overcome violence for women not only due to criminal law and criminal procedure mechanisms, but also due to the introduction of meaningful (substantial) equality between women and men).

It should be recalled that the principle of equality between women and men as an integral part of human rights is reflected in the prohibition of discrimination on grounds of sex contained in Article 14 of the European Convention on Human Rights (ECHR) 1950 and its Protocol № 12, which effective in April 2005 [9]. Protocol № 12 to the ECHR is an important tool for achieving equality between women and men, as it guarantees the provision of any statutory right without discrimination and a general prohibition of discrimination by any public authority, in particular on the grounds of sex.

Despite the fact that the ECHR is gender neutral sense of the document, in the process of interpreting the Convention as dynamic instrument, the ECHR has developed case law on women's rights, including violence against women (domestic violence, sexual violence, compulsory gynecological examination, trafficking in women), reproductive rights (abortion, sterilization, medical reproduction technology) and sex discrimination (employment, social help, etc.) [10, p. 23]. Thus, the European Convention for the Protection of Human Rights and Fundamental Freedoms is a significant document in the history of the formation of not only international law but also national human rights institutions.

In modern world, the issue of achieving gender equality and the empowerment of women and girls in the security sector is of increasing importance. The Organization for Security and Cooperation in Europe (OSCE) is the largest regional organization that deals with many issues related to security, in particular protecting human rights and promoting gender equality [11, p. 5].

The OSCE recognizes that equal rights for women and men are important in promoting peace, stable democracy and economic development. It therefore aims to ensure equal opportunities for women and men, as well as to integrate gender equality into policies and practices in both Member States and the Organization. Emphasis is placed on empowering women, building local competence and acquiring expertise in gender issues, as well as cooperating with the authorities in reviewing legislation, and developing national mechanisms to ensure equality between women and men [12, p. 105].

The OSCE has adopted a number of legal acts and commitments related to gender equality such as: Code of Conduct on Politico-Military Aspects of Security, Ministerial Council Decision 14/04 - 2004 OSCE Action Plan for the Promotion of Gender Equality, Decision 14/05 women in conflict prevention, crisis management and post-conflict rehabilitation, Decision 15/05 preventing and combating violence against women, Gender 
and Security Sector Reform Toolkit, Decision 7/09 women's participation in political and public life, Decision 10/11 promoting equal opportunities for women in the economic sphere, Decision $7 / 14$ preventing and combating violence against women etc.

The OSCE Action plan for the promotion of gender equality [13] lays the main foundation for OSCE action in the field of gender equality and recognizes the direct link between equality between women and men and "ensuring peace, sustainable democracy, economic development and, consequently, security and stability in the OSCE region". The OSCE Action Plan calls for increased efforts to achieve equal treatment of women and men in the Organization in all areas, including recruitment, and to reflect gender issues in the Organization's activities. This plan provided a better understanding of the need to improve the gender mainstreaming in the OSCE.

Equality between women and men is one of the fundamental principles of the functioning of the European Union (EU). For many years, the principle of gender equality has been governed by EU law, which obliges Member States to ensure equal opportunities and equal treatment for men and women, as well as to combat all forms of discrimination on grounds of sex. For the first time the idea of equal rights and opportunities for women and men was recorded in the Treaties of Rome (1957). In particular, Article 119 states that "men and women should receive equal pay for equal work", "equal pay without discrimination on the basis of sex".

Moreover, the EU is founded on a set of values, including equality. It promotes equality between men and women (Arts. 2 and 3(3) of the Treaty on European Union (TEU) [14]). In the EU Charter of Fundamental Rights (2000) Article 21 deals with prohibition discrimination based on a number of characteristics, including gender. In addition, Article 8 of the Treaty on the Functioning of the European Union (TFEU) [14] gives the Union the task of eliminating inequalities and promoting equality between men and women through all its activities (this concept is also known as "gender mainstreaming") [15].

In the Maastricht Treaty (1992), Article 2 deals with values characterized by pluralism, non-discrimination, tolerance, justice, solidarity and equality of women and men. In Article 3 It states that the EU "fights against social marginalization and discrimination, promotes social justice and social protection, equality between women and men, intergenerational solidarity and the protection of children's rights".

The Treaty of Amsterdam (1997) prescribes the idea of "equality between men and women on labor market opportunities and in relation to treatment at work" (art. 118), "equal treatment for men and women in respect of employment and occupation, including the principle of equal pay for equal work", "ensuring full equality between men and women in working life" (Article 119).

The Lisbon Treaty, which entered into force on 1 December 2009 and is considered a significant step in the EU's democratization process, has led to the further development of the principle of gender equality. The Treaty emphasizes the importance of the principles of non-discrimination and equality as fundamental principles of EU law. The Lisbon Treaty adds to the issue of gender equality in the labor market (Articles 1 and 2) and the fight against discrimination on the grounds of sex (Article 5) such as combating trafficking in human beings, in particular women and children (Articles $63,69)$, overcoming domestic violence. Article 10 TFEU states that "in defining and implementing policies and actions, the Union shall aim to combat discrimination based on sex, racial or ethnic origin, religion 
or belief, [physical or mental] disability, age or sexual orientation" [14]. In addition, Art. 19 TFEU contains legal regulation of the procedure for taking appropriate measures to combat discrimination based on sex, racial or ethnic origin, religion or belief, [physical or mental] disability, age or sexual orientation.

It should be noted that the implementation of the principles of gender equality was strengthened by the establishment in 2006 of the European Institute for Gender Equality (EIGE), the purpose of which is to integrate the principles of equality into the policies of the EU and member states, to overcome gender discrimination, promoting awareness of citizens on gender equality [16, p. 73].

Although the EU has achieved positive results in protecting human rights, work is still continuing in this direction. The idea of gender equality is an integral part of equality as a general principle, development and peace in the world. Without this principle, it is impossible to establish the basis for democracy, freedom, justice and tolerance.

Recently, the principle of gender equality is getting paramount importance for Ukraine, as one of the conditions for successful European integration. In the national legal system, gender equality is guaranteed, first of all, by the Constitution of Ukraine, the Labor Code of Ukraine, as well as by the special Law of Ukraine "On the Guarantee of Equal Rights and Opportunities for Women and Men" (2005) and other legislative acts.

Ukraine, like all civilized nations, is also actively pursuing a gender policy based on generally accepted international norms enshrined, in particular, in the Universal Declaration human rights, the Convention on the Political Rights of Women, the Convention on the elimination of all forms of discrimination against women and other documents. Ukraine shares the principles of the United Nations and the under- standing of gender equality as a necessary condition for achieving sustainable development of the country, creating conditions for the comprehensive development of human potential [17, p. 5].

Ukraine's European integration provides for the harmonization of domestic legislation in order to achieve in practice high European standards for the regulation of gender relations. Modern state policy of Ukraine should be aimed at overcoming all forms and manifestations of discrimination on the grounds of sex, to create a political basis and the necessary social conditions for the fullest realization of the natural ability of women and men in all spheres of work, social and personal life.

Conclusions. To sum up, gender equality is an integral condition for the full realization of human rights, against true democracy requires equal participation of women and men in public life. However, despite the enormous efforts of the international community, there are still real obstacles for women in many areas, including the labor market, where their share of the highest paid sectors is steadily declining. Women are underrepresented in leadership positions and among decision-makers in political and leadership positions. And although the existence of gender discrimination is recognized by most experts, politicians and scholars, which are seriously discussed, many of its forms and manifestations remain in the shadows.

The article is devoted to the formation of development and legal regulation of the principle of gender equality in international law, which is referred to the level of values of the European Union (EU), and also plays an important role for Ukraine due to the context of European integration. Today, the attitude towards women in society is significantly different from the attitude towards men and this applies to different spheres of life: social, political, legal. Thus, political gender inequality includes less 
representation of women in elected positions and lower representation in political and corporate circles. Gender equality means the existence of a society in which both women and men have equal opportunities, rights and responsibilities in all spheres of life. Equality between women and men is equal access to education and health care, governance and power for both sexes, their equal opportunities for financial independence, and the realization of their personal and professional needs and interests.

One of the most significant developments in international law in the middle of the twentieth century was the consolidation of the principle of non-discrimination and the further development of international and regional legal standards aimed at improving and protecting the rights of all women and girls. At the same time, the protection of women and girls, as well as men and boys, is first and foremost the responsibility of the state. International law establishes the obligation of states to protect their own citizens, including against gender discrimination. Currently, gender equality is gaining priority in the activities of international organizations.

At the present stage of development of society, the issues of gender equalities are not the last place in terms of relevance. Gender inequality slows down the development of society. That is why the achievement of gender equality is now becoming a central indicator of the development of each country.

Key words: gender equality, women's rights, human rights, international organizations, discrimination, legal regulation.

Ріонідзе Х. Еволюція міжнародно-правового регулюваннягендерної рівності

Наукова стаття присвячена формуванню розвитку та пра- вового регулювання принципу гендерної рівності в міжнародному праві, який належить до иінностей Європейського Союзу (EC), а також відіграе важливу роль для України в умовах європейської інтеграції. Сьогодні ставлення до жінок у суспільстві істотно відрізняеться від ставлення до чоловіків, $i$ це стосується різних сфер життя: соціальної, політичної, правової. Таким чином, політична гендерна нерівність включае меншу представленість жінок на виборних посадах та в політичних колах. Гендерна рівність означає існування суспільства, в якому $i$ жінки, $i$ чоловіки мають рівні можливості, права та обов'язки y всіх сферах життя. Рівність між жінками та чоловіками - це однаковий доступ до освіти та охорони здоров'я, рівні можливості для фінансової незалежності mа реалізащії їніх особистих $i$ nрофесійних інтересів тощо.

Однією з найбільш значних подій y міжнародному праві середини ХX столітmя стало закріплення принциипу недискримінаціі та подальший розвиток міжнародних та регіональних правових стандартів, спрямованих на покращення та захист прав усіх жінок та дівчат. Водночас захист жінок та дівчат, а також чоловіків та хлопчиків - ие перш за все відповідальність держави. Міжнародне право встановлюе обов'язок держав захищати власних громадян, зокрема й від гендерної дискримінації. Hamепер гендерна рівність набувае пріоритету в діяльності міжнародних організаијіü.

На сучасному етапі розвитку суспільства питання гендерної рівності займають не останне місиее за актуальністю, адже нерівність за статевою ознакою вповільнюе розвиток суспільства. Ось чому досягнення гендерної 
рівності зараз стає иентральним показником розвитку кожної країни.

Ключові слова: гендерна рівність, права жінок, права людини, міжнародні організації, дискримінація, правове регулювання.

\section{References}

1. Universal Declaration of Human Rights 1948. URL: https: / / www.un.org / en / about-us / universal-declaration-ofhuman-rights (Last accessed: 28.09.2021)

2. Convention on the Elimination of All Forms of Discrimination against Women 1979. URL: https: //www.ohchr.org/en/ professionalinterest / pages / cedaw.aspx (Last accessed: 28.09.2021)

3. World Conferences on Women. UN Women. URL: https: / / www.unwomen.org / en / how-we-work/intergovernmental-support/world-conferences-on-women (Last accessed: 28.09.2021)

4. Слова $i$ голос. Words and Voice. Тематична експозичія : Підготовлена в рамках IV Харківського міннародного юридичного форуму Науковою бібліотекою Національного юридичного університету імені Ярослава Мудрого. 2020. 32 c. URL: http://library.nlu.edu.ua/ Biblioteka/sait/Slovo.pdf (Last accessed: 28.09.2021)

5. Гендерна рівність та права жінок : навч. курс. Практично-методичний посібник викладача. Київ, 2020. 168 с. URL: https: / / newiustice.org.ua/wp-content / uploads / 2020/02 / Curriculum-Gender-Equality-Final.pdf (Last accessed: 28.09.2021)

6. Equality between women and men, The Council of Europe URL: https: / / rm.coe.int / CoERMPublic CommonSearchServices / Disp layDCTMContent? documentId $=0900001680$ 64f51b (Last accessed: 28.09.2021)

7. Gender Equality Strategy 2018-2023. URL: https: / / www.coe.int/en/web/genderequality/gender-equality-strategy (Last accessed: 28.09.2021)

8. The four pillars of the Istanbul Convention Council of Europe Convention on preventing and combating violence against women and domestic violence. URL: https://rm.coe.int/ coe-istanbulconvention-brochure-en- r03-v01/1680a06d4f (Last accessed: 28.09.2021)

9. European Convention on Human Rights 1950. URL: https: / / www.echr.coe.int/ Pages / home.aspx? p=basictexts\&c (Last accessed: 28.09.2021)

10. Уварова О.О. Права жінок та гендерна рівність : навч. посіб. Київ : видавництво «ФОП Голембовська О.О.», 2018. 204 c. URL: https: / / nlu.edu.ua/wp-content / uploads / 2021/05/msc_9_copy.pdf (Last accessed: 28.09.2021)

11. Добробут $i$ безпека жінок. Дослідження насильства над жінками в Україні. Проведено під керівництвом ОБСЕ, 2019 p. URL: https: / / www.osce.org / files / f/documents /0/8/440318_0.pdf (Last accessed: 28.09.2021)

12. Камінська Н., Свєшнікова М. Діяльність міжнародних організацій у сфері забезпечення гендерної рівності. Юридичний часопис Національної академії внутрішніх cправ. 19, 1 (Чер 2020), 102-109. URL: https: / / philosophy. naiau.kiev. ua/index.php / lawjournal/article / view/1215/1219 (Last accessed: 28.09.2021)

13. Ministerial Council Decision No. 14/04 - 2004 OSCE Action Plan for the Promotion of Gender Equality. URL: https: / / www.osce.org/mc/23295 (Last accessed: 28.09.2021)

14. Consolidated versions of the Treaty on European Union and the Treaty on the Functioning of the European Union 2012/C 326/01. URL: https: / / eur-lex.europa.eu/legal-content / EN / TXT / ? uri $=$ celex $\% 3 A 12012 \mathrm{M} \% 2$ FTXT (Last accessed: 28.09.2021)

15. Equality between men and women by Martina Schonard 10-2018. URL: ht tp: / / www.europarl.europa.eu / factsheets / en/sheet / 59 / equality-between-men-and-women (Last accessed: 28.09.2021)

16. Гончарова Ю.А. Роль та місце принципу гендерної рівності в сучасному міжнародному праві : дис. ... канд. юрид. наук : 12.00.11. Харків, 2017. 200 c.

17. Гендерна рівність $i$ розвиток: погляд у контексті європейської стратегії України. Центр Разумкова. Київ : Видавництво «Заповіт», 2016 p. 244 c. URL: https: / / razumkov.org.ua/upload / Gender-FINAL-S.pdf (Last accessed: 28.09.2021 